\title{
ENERGI METABOLIS DAN KECERNAAN PROTEIN RANSUM YANG MENGANDUNG TEPUNG KULIT SINGKONG TERFERMENTASI PADA BURUNG PUYUH (Coturnix coturnix japonica) JANTAN Metabolism Energy And Protein Digestibility In The Diet Containing Fermented Cassava Peel Meal Of Male Quail (Coturnixcoturnix Japonica)
}

\author{
Siti Nur Na'imah ${ }^{1}$, Warsono Sarengat ${ }^{2}$ dan Bambang Sukamto $^{2}$ \\ ${ }^{1}$ Siti Nur Na'imah, Program Studi S1 Peternakan, Fakultas Peternakan dan Pertanian \\ Universitas Diponegoro, Semarang \\ Email : Sitinaimah2012@gmail.com \\ ${ }^{2}$ Fakultas Peternakan dan Pertanian Universitas Diponegoro, Semarang \\ Kompl. drh. R. Soejono Koesoemowardojo - Tembalang, Semarang, \\ Kode Pos: 50275
}

\begin{abstract}
ABSTRAK
Tujuan dari penelitian ini adalah untuk mengetahui pengaruh penggunaan tepung kulit singkong terfermentasi dalam ransum terhadap energi metabolis dan kecernaan protein burung puyuh jantan. Penelitian ini dilaksanakan pada tanggal 24 Juni - 31 Agustus 2016 di Kandang Fakultas Peternakan dan Pertanian Universitas Diponegoro Semarang. Materi yang digunakan adalah burung puyuh jantan umur 2 minggu sebanyak 200 ekor dengan bobot badan rata-rata sebelum perlakuan 30,03 $\pm 3,36$ gram $(\mathrm{CV}=12,31 \%)$ diperoleh dari peternakan di Colomadu, Boyolali. Bahan ransum yang digunakan yaitu jagung, bungkil kedelai, bekatul, tepung ikan, tepung kulit singkong fermentasi dan PMM. Perlakuan terdiri dari T0 (ransum tanpa penggunaan tepung kulit singkong fermentasi), T1 (ransum dengan penggunaan tepung kulit singkong fermentasi 5\%), T2 (ransum dengan penggunaan tepung kulit singkong fermentasi 10\%), T3 (ransum dengan penggunaan tepung kulit singkong fermentasi 15\%). Data diuji dengan analisis ragam berdasarkan Rancangan Acak Lengkap (RAL) dengan uji $\mathrm{F}$ dan bila hasil menunjukkan pengaruh nyata maka dilanjutkan dengan uji jarak berganda Duncan. Hasil penelitian menunjukkan energi metabolis dan kecernaan protein tidak berpengaruh nyata $(\mathrm{P}>0,05)$. Simpulan penelitian adalah kulit singkong terfermentasi dapat digunakan dalam ransum burung puyuh jantan hingga $15 \%$.
\end{abstract}

Kata Kunci : energi metabolis, kecernaan protein, tepung kulit singkong terfermentasi, dan burung puyuh jantan

\section{ABSTRACT}

This research is aimed to determine the effect of using fermented cassava peel flour in feeds towards metabolism energy and protein digestibility of quail. This research is conducted on 24 June - 31 August 2016 at a cage owned by Faculty of Agriculture and 
Animal Agriculture, University of Diponegoro, Semarang. The material used is 200 numbers of quails in the age of 2 weeks by weight average 30,03 $\pm 3,36$ gram $(C V=$ $12,31 \%)$ before giving treatment. It is taken from an animal agriculture in Colomadu, Boyolali. The material used in feeds are corn, soybean, rice bran, fish meal, fermented cassava peel flour and PMM. The treatment consists of TO (feeds without the use of fermented cassava peel flour), T1 (feeds with 5\% use of fermented cassava peel flour), T2 (feeds with 10\% use of fermented cassava peel flour), T3 (feeds with 15\% use of fermented cassava peel flour). The data is tested using random analysis according to Complete Random Design (RAL) with test $F$ and if the result shows a significant effect, then it is continued by Duncan Multiple Range Test. The research result showed that metabolism energy is not affected in real $(P>0,05)$, meanwhile is not affected in real $(P>0,05)$ in protein digestibility. The research conclusion can be drawn that the use of fermented cassava peel flour upto the level of $10 \%$ in feeds can decrease metabolism energy of quail and protein digestibility of quail at once.

Keywords: metabolism energy, protein digestibility, fermented cassava flour, and quail

\section{PENDAHULUAN}

Pengembangan burung puyuh dapat dilakukan untuk usaha kecil, menengah hingga ke peternakan besar. Burung puyuh jantan berpotensi untuk dikembangkan karena mudah dipelihara, biaya pemeliharaan tidak terlalu besar serta dapat diusahakan pada lahan yang tidak terlalu luas (Mahfudz dkk., 2010). Pada umumnya burung puyuh dimanfaatkan produksi telurnya, namun untuk yang pejantan bisa dimanfaatkan produksi dagingnya. Faktor penting yang mempengaruhi produktivitas burung puyuh adalah pakan. Masalah yang sering dijumpai dalam penyediaan pakan adalah masalah biaya pakan yang relatif mahal dan ketersediaannya yang tidak tetap sepanjang tahun. Salah satu upaya yang dapat dilakukan adalah dengan melakukan pemberian pakan alternatif yang lebih murah dan mudah akan tetapi masih mempunyai kandungan nutrisi yang cukup tinggi sebagai pakan ternak.

Bahan pakan alternatif dapat berasal dari limbah pertanian yang tidak termanfaatkan. Kulit singkong merupakan limbah dari pengupasan umbi singkong. Potensi singkong sendiri di Indonesia sangat besar dan ketersediaannya tetap ada sepanjang tahun. Setiap singkong akan menghasilkan kulit singkong sebesar 16\% dari total beratnya (Supriyadi, 1995). Kulit singkong mempunyai zat anti nutrisi HCN yang dapat dikurangi dengan perlakuan fisik dan biologis. Perlakuan fisik dapat dilakukan dengan cara pemanasan, pencacahan dan perendaman. Perlakuan biologis dapat dilakukan dengan cara fermentasi (Prasetyo, 2005).

Kebutuhan zat-zat nutrisi terutama protein dan energi harus diperhatikan dalam pemberian pakan, karena tingkat produksi puyuh dipengaruhi oleh zat nutrisi tersebut. Nilai energi metabolis memberikan gambaran potensi pakan dalam memenuhi kebutuhan energi untuk hidup pokok dan produksi. Nilai protein kasar memberikan informasi awal pakan dalam memenuhi kebutuhan protein ternak. Bila energi metabolis dan protein ransum hanya cukup untuk hidup pokok maka pertumbuhan ternak akan terlambat, demikian juga produksi ternak akan menurun bahkan berhenti.

Tujuan dari penelitian ini adalah untuk mengetahui pengaruh penggunaan tepung kulit singkong terfermentasi 
terhadap energi metabolis dan kecernaan protein burung puyuh jantan. Penelitian diharapkan dapat memberikan pengaruh terhadap performa burung puyuh khususnya pada energi metabolis dan kecernaan protein sehingga menjadi lebih baik.

\section{MATERI DAN METODE}

Penelitian telah dilaksanakan pada 24
Juni - 31 Juli 2016 di Kandang Fakultas Peternakan dan Pertanian, Universitas Diponegoro, Semarang. Penelitian menggunakan burung puyuh (Cotrunixcotrunix japonica) jantan umur 2 minggu sebanyak 200 ekor dengan bobot rata-rata $30,03 \pm 3,36$ gram $(\mathrm{CV}=12,31 \%)$. Komposisi dan kandungan nutrisi ransum dapat dilihat pada tabel 1 .

Tabel 1. Kandungan Nutrisi Ransum Perlakuan

\begin{tabular}{lcccc}
\hline \multirow{2}{*}{ Bahan Pakan } & \multicolumn{4}{c}{ Perlakuan } \\
\cline { 2 - 5 } Ty & T0 & T1 & T2 & T3 \\
\hline TKST & 0 & 5 & 10 & 15 \\
Jagung kuning & 42 & 39,5 & 36,5 & 35,5 \\
Bekatul & 30,5 & 29 & 27 & 24 \\
Tepung ikan & 4 & 4 & 4 & 4 \\
Bungkil kedelai & 19,5 & 18,5 & 20 & 16,5 \\
PMM & 4 & 4 & 2,5 & 5 \\
Jumlah & $\mathbf{1 0 0}$ & $\mathbf{1 0 0}$ & $\mathbf{1 0 0}$ & $\mathbf{1 0 0}$ \\
Kandungan Nutrisi & & & & \\
Energi Metabolis (kkal/kg) & 2894,83 & 2863,19 & 2818,94 & 2800 \\
Protein Kasar (\%) & 20,42 & 20,14 & 20,00 & 20,03 \\
Serat Kasar (\%) & 3,31 & 4,77 & 6,11 & 7,70 \\
Lemak Kasar (\%) & 4,60 & 4,43 & 4,05 & 3,99 \\
Ca (\%) & 0,69 & 0,68 & 0,62 & 0,68 \\
P (\%) & 0,72 & 0,71 & 0,69 & 0,70 \\
\hline
\end{tabular}

Hasil analisis proksimat Laboratorium Ilmu Nutrisi dan Pakan, Fakultas Peternakan dan Pertanian, Universitas Diponegoro, 2016.

Pembuatan tepung kulit singkong fermentasi mengacu pada Darma dkk. (1991) yaitu kulit singkong dicuci dengan air bersih untuk dihilangkan kotorannya yang menempel, setelah bersih ditiriskan dan dikeringkan. Kulit singkong yang telah kering tersebut di iris-iris kecil-kecil atau digiling yang bertujuan untuk memperluas permukaan fermentasi. Kemudian dikukus dengan penambahan lebih dahulu air bersih pada kulit singkong giling. Pengukusan dilakukan selama 30 menit dihitung pada saat uap air mulai keluar dari permukaan atas kulit singkong yang dikukus, diangkat lalu didinginkan. Setelah dingin kulit singkong ditambahkan atau ditaburi dengan enzim dan asam yang dihasilkan oleh jamur Aspergillus niger lalu simpan pada tempat tertutup dan kedap udara selama 1 minggu.

Rancangan penelitian yang digunakan adalah Rancangan Acak Lengkap (RAL) dengan 4 perlakuan dan 5 ulangan. Data yang dihasilkan dianalisis menggunak ANOVA dan uji $F$ untuk mengetahui pengaruh perlakuan jika berbeda nyata. Perlakuan yang diberikan sebagai berikut:

$\mathrm{T} 0=$ (Ransum tanpa penggunaan tepung kulit singkong terfermentasi)

$\mathrm{T} 1=$ Ransum dengan penggunaan tepung kulit singkong terfermentasi 
$5 \%)$

$\mathrm{T} 2=($ Ransum dengan penggunaan tepung kulit singkong terfermentasi $10 \%)$

$\mathrm{T} 3=($ Ransum dengan penggunaan tepung kulit singkong terfermentasi $15 \%)$.

Total koleksi dilakukan setelah puyuh berumur 6 minggu. Selama total koleksi dilakukan 3 tahap perlakuan, tahap pertama dilakukan pemuasaan selama 24 jam pada puyuh, guna untuk mengosongkan saluran pecernaan. Tahap kedua puyuh di beri pakan perlakuan selama 24 jam dan menampung eskreta. Tahap ketiga dilakukan pemuasaan 24 jam untuk membersihkan sisa hasil pencernaan, selama pemuasaan puyuh tetap diberi minum (Maghfiroh, 2012). Selama total koleksi, dilakukan penyemprotan ekskreta dengan $\mathrm{HCl} \quad 0,2 \mathrm{~N}$ untuk mencegah penguapan nitrogen, kemudian mengeringkan ekskreta, menghaluskan dan menganalisis kandungan ekskreta. Data yang diperoleh digunakan untuk menghitung kecernaan protein dan energi metabolis.

Perhitungan Energi Metabolis (EM) berdasarkan rumus Sibbald (1983) yaitu :

Energi Metabolis Semu $=\frac{\text { E.intake }(\mathrm{kal})-\text { E.ekskreta }(\mathrm{kal})}{\text { Intake }(\mathrm{g})} \times 1 \mathrm{kal}$

Keterangan :

E. intake = Energi pakan dalam konsumsi $(\mathrm{kal} / \mathrm{g})$

GE ekskreta = Energi dalam ekskreta dari pakan perlakuan $(\mathrm{kal} / \mathrm{g})$

Intake $\quad=$ Jumlah pakan yang dikonsumsi $(\mathrm{g})$

Kecernaan protein ditentukan dengan menggunakan persamaan menurut Mc Donald dkk. (1988) yaitu:

Kecernaan Protein $(\%)=\frac{\text { Konsumsi Protein }- \text { Protein Ekskreta }}{\text { Protein Protein }} \times 100 \%$

Keterangan:

Konsumsi protein : (konsumsi pakan \%BK) x \%PK dalam pakan

Protein ekskreta : (berat ekskreta \%BK) x \%PK dalam ekskreta

PK : protein kasar

BK : Bahan kering

\section{HASIL DAN PEMBAHASAN}

Jumlah rata-rata energi metabolis dan kecernaan protein burung puyuh jantan selama perlakuan penggunaan kulit singkong terfermentasi disajikan pada Tabel 2. Hasil menunjukkan bahwa perlakuan penggunaan kulit singkong terfermentasi tidak berbeda nyata $(\mathrm{P}>0,05)$ terhadap nilai energi metabolis burung puyuh jantan dan juga pada kecernaan protein pada burung puyuh jantan. Tabel 2. Rata-rata energi metabolis dan kecernaan protein burung puyuh jantan selama perlakuan 


\begin{tabular}{lcccc}
\hline \hline \multirow{2}{*}{ Parameter } & \multicolumn{4}{c}{ Perlakuan } \\
\cline { 2 - 5 } & T0 & T1 & T2 & T3 \\
\hline Energi Metabolis (kka1/kg) & 2775,76 & 2785,07 & 2710,48 & 2626,75 \\
Kecernaan Protein (\%) & 77,60 & 76,39 & 76,07 & 75,56 \\
\hline
\end{tabular}

Keterangan : Nilai rata-rata menunjukkan tidak ada perbedaan yang nyata $(\mathrm{P}>0.05)$

\section{Energi Metabolis}

Hasil penelitian menunjukkan bahwa penggunaan tepung kulit singkong terfermentasi memberikan pengaruh nyata $(\mathrm{P}>0,05)$ terhadap energi metabolis pada burung puyuh jantan. Hasil yang tidak berbeda nyata dikarenakan kandungan energi dalam ransum antar perlakuan relatif sama, dengan kandungan energi ransum berkisar pada angka $2800 \mathrm{kkal} / \mathrm{kg}$. Tinggi rendahnya nilai energi metabolis dipengaruhi oleh kandungan serat kasar dalam ransum perlakuan. Menurut Prabowo dkk. (2002) perbedaan energi metabolis disebabkan oleh perbedaan kandungan serat kasar antar perlakuan. Semakin rendah serat kasar, maka semakin tinggi energi metabolis. Sebaliknya, semakin tinggi serat kasar, maka semakin rendah energi metabolis.

Hasil penelitian menunjukkan bahwa energi metabolis pada burung puyuh tergolong rendah, dengan rata-rata yaitu 2724,51. Hasil tersebut berbeda dengan penelitian yang dilaksanakan oleh Yuniarti, dkk. (2016) menyatakan energi metabolis pada burung puyuh berkisar pada angka $3256,20 \mathrm{kkal} / \mathrm{kg}$. Rendahnya nilai energi metabolis pada burung puyuh disebabkan semakin meningkatnya kandungan serat kasar didalam ransum perlakuan, sehingga menjadi faktor pembatas dalam pakan unggas. Amrullah (2003) menyatakan bahwa ransum yang mengandung serat kasar tinggi bersifat amba dan menghasilkan nilai energi yang rendah. Faktor lain yang menyebabkan tinggi rendahnya energi metabolis adalah kemampuan setiap individu ternak dalam mencerna ransum berbeda-beda. Dianti dkk., (2012) menyatakan jika ternak diberi ransum dengan kandungan nutrisi yang sama sesuai dengan kebutuhan, maka ternak akan mengonsumsi ransum dalam jumlah yang sama sesuai dengan kebutuhan periodenya.

\section{Kecernaan Protein}

Hasil penelitian menunjukkan bahwa penggunaan tepung kulit singkong terfermentasi dalam ransum tidak berpengaruh nyata $(\mathrm{P}>0,05)$ terhadap kecernaan protein pada burung puyuh jantan. Kecernaan protein yang tidak berbeda nyata dikarenakan kandungan ransum antar perlakuan T0, T1, T2 dan T3 tidak berbeda, dengan kadar protein ransum berkisar pada angka $20 \%$. Menurut Listyowati dan Roospitasari (2000) burung puyuh periode grower membutuhkan protein dalam pakan sebanyak $20 \%$.

Menurut Rubiyanti dkk. (2010) kecernaan adalah indikasi awal ketersediaan berbagai nutrisi yang terkandung dalam bahan pakan tertentu bagi ternak yang mengkonsumsinya. Berdasarkan hasil penelitian, rata-rata kecernaan protein pada burung puyuh jantan adalah 76,47\%. Hal ini menunjukkan bahwa hasil kecernaan protein relatif tinggi, sesuai dengan pendapat Anggorodi (1995) yang menyatakan kualitas ransum berdasarkan daya cerna dibagi menjadi 3 kategori, yaitu: nilai kecernaan pada kisaran $50-60 \%$ adalah kualitas rendah, $60-70 \%$ kualitas sedang dan diatas $70 \%$ kualitas 
tinggi. Kecernaan yang tinggi menunjukkan semakin tinggi pula zat-zat pakan yang diserap tubuh ternak. Irawan dkk. (2012) mengungkapkan pakan yang dikonsumsi oleh ternak akan berpengaruh terhadap tingkat konsumsi, kecernaan pakan, pertambahan bobot badan, dewasa kelamin, produksi telur dan kualitas telur yang dihasilkan.

Pernyataan berbeda di kemukakan oleh Schaible (1979) bahwa bahan pakan yang berkualitas baik mempunyai nilai kecernaan protein minimal 85\%, yang artinya semakin sedikit protein yang tercerna maka semakin sedikit pula kebutuhan protein untuk pertumbuhan yang terpenuhi. Hidayat (2009) menyatakan bahwa hal tersebut dikarenakan protein yang dihasilkan dari proses fermentasi merupakan protein sel tunggal (PST) yang di dominasi oleh RNA (ribonucleic acids), RNA dalam bahan pakan terfermentasi akan menjadi faktor pembatas karena dapat menyebabkan gangguan metabolisme dalam tubuh ternak.

\section{KESIMPULAN}

Penggunaan tepung kulit singkong terfermentasi dapat dimanfaatkan sebagai bahan pakan penyusun ransum hingga taraf $15 \%$.

\section{DAFTAR PUSTAKA}

Amrullah, I. K. 2003. Nutrisi Ayam Petelur. Cetakan I. Lembaga Satu Gunung Budi Kompleks IPB, Bogor.

Anggorodi, R. 1995. Ilmu Makanan Ternak Umum. Cetakan V, Gramedia Pustaka Utama, Jakarta.

Darma, J., T. Purwadaria Dan Supriyati. 1991. Protein Enrichment; Study Cassava Enrichment Melalui Proses
Biologi Untuk Ternak Monogastrik. Laporan Penelitian. Balai Penelitian Ternak, Bogor.

Dianti, R. Mulyono, F. dan Wahyono, 2012. Pemberian daun Crostalaria usaramoensis sebagai sumber protein ransum burung puyuh periode grower terhadap energi metabolis, retensi nitrogen dan efisiensi ransum. Animal Agricultural Juounal. 1 (1): 203214.

Hidayat, C. 2009. Peluang Penggunaan Kulit Singkong Sebagai Pakan Unggas. Balai Penelitian Ternak. Bogor.

Irawan, I., D, Sunarti dan L. D. Mahfudz. 2012. Pengaruh pemberian pakan bebas pilih terhadap kecernaan protein burung puyuh (Cotunix cotunix japonica). Fakultas Peternakan dan Pertanian, Universitas Diponegoro, Semarang. Animal Agliculture Journal. 1 (2): 238-245.

Listiyowati, E. dan Roospitasari, K., 2000. Puyuh : Tata Laksana Budi Daya Secara Komersial. Penebar Swadaya, Jakarta.

Maghfiroh, K., I. Mangisah dan V.D.Y.B. Ismadi. 2012. Pengaruh penambahan sari jeruk nipis (Citrus aurantifolla) dalam ransum terhadap kecernaan protein kasar dan retensi nitrogen pada itik magelang jantan. Animal Agriculture Jurnal 1 (1) : 669-683.

Mahfudz, L. D., T. A. Sarjana, W. Sarengat. 2010. Efisiensi penggunaan protein ransum yang mengandung limbah destilasi minuman beralkohol (ldmb) oleh burung puyuh (coturnix coturnix japonica) jantan. Seminar Nasional 
Teknologi Peternakan dan Supriyadi. 1995. Pengaruh tingkat Veternier. Semarang.

McDonald, P., R.A. Edwards, and J.F.D.

Greenhalgh. 1988. Animal

Nutrition. John Willey and Sons

Inc., New York. p. 96-105.

Prabowo, A., Zuprizal dan T. Yuwanto. 2002. Evaluasi kandungan nutrien, energi metabolis, kecernaan protein in vitro, kelarutan dan berat molekul protein serta kandungan asam amino eceng gondok. Jurnal Agrosains 15 (1) : 99-110.

Prasetyo, H. 2005. Pengaruh Penggunaan kulit Ubi Kayu (Manihot utilisima) Fermentasi sebagai Subsitusi Konsentrat Komersial Terhadap Performan Domba Lokal Jantan. Fakultas Pertanian Universitas Sebelas Maret Surakarta. Skripsi.

Rubiyanti, A., P.Th. Fernandez, H.H Marawali dan E. Budisantoso. 2010. Kecernaan Bahan Kering dan Bahan Organic Hay Clitoria Ternatea dan Centrocema Pascuorum $\mathrm{Cv}$ Cavalcade pada Sapi Bali Lepas Sapih. Seminar Nasional Teknologi Peternakan dan Veternier

Schaible, P.J. 1979. Feeds and Nutrition. Third Edition. The AVI publishing Co, Wesport; Connecticut.

Sibbald, I. R. and M. S. Wolynetz. 1985. Estimates of retained nitrogen used to correct estimates of bioavailable energy. Poultry Sci. 64: 1506-1513.

Sulistiani, E. 2012. Tingkat Penggunaan Tepung daun Lamtoro (Leucaena leucocephala) terhadap Kecernaan Protein dan Konsumsi Energi Metabolisme pada Burung Puyuh (Cortunix cortunix japonica). Universitas Hasanuddin Makassar. Makassar. 